\title{
Assessment of Cytotoxicity of Magnesium Oxide and Magnesium Hydroxide Nanoparticles using the Electric Cell-Substrate Impedance Sensing
}

\author{
Manishi Pallavi ${ }^{1,2,3}$, Jenora Waterman $\left.{ }^{4} \mathbb{(}\right)$, Youngmi Koo ${ }^{2,3}$, Jagannathan Sankar ${ }^{2,5}$ \\ and Yeoheung Yun ${ }^{2,3, *}$ \\ 1 Department of Energy and Environmental Systems, North Carolina Agricultural and Technical State \\ University, Greensboro, NC 27411, USA; mpallavi@aggies.ncat.edu \\ 2 Engineering Research Center for Revolutionized Metallic Biomaterials, North Carolina Agricultural and \\ Technical State University, Greensboro, NC 27411, USA; kooym20120503@gmail.com (Y.K.); \\ sankar@ncat.edu (J.S.) \\ 3 Department of Chemical, Biological and Bioengineering, North Carolina Agricultural and Technical State \\ University, Greensboro, NC 27411, USA \\ 4 Department of Animal Sciences, North Carolina Agricultural and Technical State University, \\ Greensboro, NC 27411, USA; jdwaterm@ncat.edu \\ 5 Department of Mechanical Engineering, North Carolina Agricultural and Technical State University, \\ Greensboro, NC 27411, USA \\ * Correspondence: yun@ncat.edu
}

Received: 2 March 2020; Accepted: 18 March 2020; Published: 20 March 2020

\begin{abstract}
Magnesium (Mg)-based alloys have the potential for bone repair due to their properties of biodegradation, biocompatibility, and structural stability, which can eliminate the requirement for a second surgery for the removal of the implant. Nevertheless, uncontrolled degradation rate and possible cytotoxicity of the corrosion products at the implant sites are known current challenges for clinical applications. In this study, we assessed in vitro cytotoxicity of different concentrations (0 to $50 \mathrm{mM}$ ) of possible corrosion products in the form of magnesium oxide $(\mathrm{MgO})$ and magnesium hydroxide $\left(\mathrm{Mg}(\mathrm{OH})_{2}\right)$ nanoparticles (NPs) in human fetal osteoblast (hFOB) 1.19 cells. We measured cell proliferation, adhesion, migration, and cytotoxicity using a real-time, label-free, non-invasive electric cell-substrate impedance sensing (ECIS) system. Our results suggest that $1 \mathrm{mM}$ concentrations of $\mathrm{MgO} / \mathrm{Mg}(\mathrm{OH})_{2}$ NPs are tolerable in hFOB 1.19 cells. Based on our findings, we propose the development of innovative biodegradable Mg-based alloys for further in vivo animal testing and clinical trials in orthopedics.
\end{abstract}

Keywords: cytotoxicity; human fetal osteoblast (hFOB) 1.19 cells; electric cell-substrate impedance sensing (ECIS) system

\section{Introduction}

Magnesium (Mg)-based alloy has a potential advantage as a biodegradable material due to its biocompatibility and structural stability in orthopedic implant applications [1]. The biodegradable implant degrades in the physiological environment of the body after healing the diseased tissues and bone fractures [2]. Thus, it can eliminate a need for a second surgery to remove the implant. However, studies suggest that $\mathrm{Mg}$-based screws and plates corrode at a very fast rate in an in vivo environment, producing subcutaneous gas cavities [3,4]. Disparity between in vitro and in vivo study results are also reported due to the different corrosive environments $[5,6]$. Therefore, there is a requirement to 
understand the cytotoxicity of the possible corrosion products for the future development of innovative Mg-based alloys in orthopedics [7].

Magnesium $\left(\mathrm{Mg}^{2+}\right)$ is the most important bivalent ion associated with the physiological functions of the body and participates actively in maintaining the cellular homeostasis [8-10]. Magnesium partakes in more than 300 biochemical reactions, mostly associated with the regulation of ion channels, intracellular signaling, and oxidative phosphorylation [11]. Studies suggest that approximately $53 \%$ of total body magnesium is stored in the bones [12-17]. Deficiency of magnesium affects the metabolism of the skeleton, which inhibits bone growth and formation of new osteoblast cells, resulting in bone brittleness $[8,18-28]$. There are many study reports on $\mathrm{Mg}$-based biodegradable orthopedic implants; however, the real-time concentration-based toxicity of the corrosion products in the form of magnesium oxide $(\mathrm{MgO})$ and magnesium hydroxide $\left(\mathrm{Mg}(\mathrm{OH})_{2}\right)$ nanoparticles (NPs) that might be released during the implant degradation process is not known.

In this study, we assessed the cytotoxicity of randomly selected different concentrations $(0,1,5$, 10 , and $50 \mathrm{mM})$ of $\mathrm{MgO} / \mathrm{Mg}(\mathrm{OH})_{2}$ NPs in hFOB 1.19 cells [7] using a real-time electric cell-substrate impedance sensing (ECIS) system. With this ECIS system, cell adhesion and proliferation have been evaluated quantitatively by the generated impedance relative to the time to measure the cytotoxicity. Studies suggest that bone hemostasis is affected by the $\mathrm{pH}$ [29]; therefore, this study also assessed the change in the $\mathrm{pH}$ to measure the cytotoxicity in hFOB 1.19 cells in response to the different concentrations of $\mathrm{MgO} / \mathrm{Mg}(\mathrm{OH})_{2} \mathrm{NPs}$. As an outcome of this novel real-time in vitro ECIS study, we report our findings for an allowable concentration of $\mathrm{MgO} / \mathrm{Mg}(\mathrm{OH})_{2} \mathrm{NPs}$ that might be released from Mg-based biodegradable alloys for its applications in future in vivo studies of orthopedic implants.

\section{Materials and Methods}

\subsection{Materials}

We purchased magnesium oxide nanoparticles (MgO NPs) (nanopowder, $<50 \mathrm{nM}$ particle size; Cat\# 549649-5G) and magnesium hydroxide nanoparticles ( $\mathrm{Mg}(\mathrm{OH})_{2} \mathrm{NPs}$ ) (nanopowder, $<100 \mathrm{nM}$ particle size; Cat\# 632309-25G) from Sigma-Aldrich, Milwaukee, WI, USA, based on our previous study [7]. Before conducting ECIS experiments, $\mathrm{MgO} / \mathrm{Mg}(\mathrm{OH})_{2} \mathrm{NPs}$ were sterilized through ultraviolet (UV) rays [7].

\subsection{Cell Culture}

In our experiments, a human osteoblast hFOB 1.19 cell line (SV40 large T antigen transfected; American Type Culture Collection) (Cat\# ATCC $® C R L-11372^{\mathrm{TM}}$, Manassas, VA, USA) were cultured in complete growth media based on our previous study [7]. Complete growth medium contained a 1:1 mixture of Ham's F12 medium with L-glutamine (Cat\#10-080-CV, Cellgro, Manassas, VA, USA) and Dulbecco's Modified Eagle's Medium with $4.5 \mathrm{~g} / \mathrm{L}$ glucose and sodium pyruvate without L-glutamine and phenol red (Cat\# 17-205-CV, Cellgro, Manassas, VA, USA), supplemented with $0.3 \mathrm{mg} / \mathrm{mL}$ gentamicin sulfate (Cat\# 17-518Z, Lonza, Walkersville, MD, USA) and 10\% fetal bovine serum (heat-inactivated at $56^{\circ} \mathrm{C}$ ) (Cat\# S1105H, Atlanta Biologicals, Flowery Branch, GA, USA) [7]. Cells were maintained under standard cell culture conditions $\left(37^{\circ} \mathrm{C}, 5 \% \mathrm{CO}_{2}\right)$ with humidified air and were utilized after three passages [7].

\subsection{Impedance Measurement}

ECIS system was utilized to study the concentration-based cytotoxicity of $\mathrm{MgO} / \mathrm{Mg}(\mathrm{OH})_{2} \mathrm{NPs}$ in hFOB 1.19 cells [7] as an alternative to the trial-and-error of animal testing. Here, array type 8W1E PET (Applied Biophysics, NY, USA) consisting of eight wells, each well with a single circular $250 \mu \mathrm{m}$ diameter active gold electrode, was used for ECIS. Arrays were attached to the ECIS system (Model ECIS Z $\theta$, Applied Biophysics, NY, USA), and alternative current (I) of $4000 \mathrm{~Hz}$ was applied to the eight-well sensing electrodes. A voltage $(\mathrm{V})$ across the electrodes created an impedance (Z), which 
was measured by Ohm's law $(\mathrm{Z}=\mathrm{V} / \mathrm{I})$. With the morphological changes in hFOB 1.19 cells in response to different concentrations of $\mathrm{MgO} / \mathrm{Mg}(\mathrm{OH})_{2} \mathrm{NPs}$ [7] in the arrays, impedance was measured.

After the third passage of the hFOB 1.19 cells in a complete growth media, $400 \mu \mathrm{L}$ of the cells (5000 cells/well) were seeded in two sets of eight-well arrays for control and experimental groups. Arrays were incubated under standard cell culture conditions $\left(37^{\circ} \mathrm{C}, 5 \% \mathrm{CO}_{2}\right)$ with humidified air for $24 \mathrm{~h} \mathrm{[7].} \mathrm{After} 24 \mathrm{~h}$, different concentrations $(0,1,5,10$, and $50 \mathrm{mM})$ of $\mathrm{MgO} / \mathrm{Mg}(\mathrm{OH})_{2} \mathrm{NPs}$ [7] were exposed to the respective wells of the arrays, followed by incubation for another $24 \mathrm{~h}$. Impedance was measured after $24 \mathrm{~h}$ of $\mathrm{MgO} / \mathrm{Mg}(\mathrm{OH})_{2} \mathrm{NP}$ exposure.

\subsection{Fluorescence Microscope}

The digital inverted fluorescence microscope (EVOS XL, Life Technologies) was utilized to observe the live images of hFOB 1.19 cells upon exposure to $\mathrm{MgO} / \mathrm{Mg}(\mathrm{OH})_{2} \mathrm{NPs}$ for $24 \mathrm{~h}$ on the microelectrodes of the arrays. The fluorescence microscope was utilized because of the unique high resolution and high sensitivity of the camera.

\subsection{The $\mathrm{pH}$ Measurement}

After treating the hFOB 1.19 cells with different concentrations of $\mathrm{MgO} / \mathrm{Mg}(\mathrm{OH})_{2} \mathrm{NPs}$, $\mathrm{pH}$ values of the control and experimental groups was measured at $24 \mathrm{~h}$. The $\mathrm{pH}$ values were measured with a $\mathrm{pH}$ meter (Oakton $\AA \mathrm{pH} 2100$, Eutech Instruments, Singapore) to evaluate the cytotoxicity of $\mathrm{MgO} / \mathrm{Mg}(\mathrm{OH})_{2}$ NPs in a time- and concentration-dependent manner.

\subsection{Statistical Analysis}

Impedance with respect to time was measured by the one-way analysis of variance (ANOVA) technique by GraphPad Prism version 5.0 software (GraphPad Software, Inc., San Diego, CA). The change in the $\mathrm{pH}$ of media of control and experimental groups for $\mathrm{MgO} / \mathrm{Mg}(\mathrm{OH})_{2} \mathrm{NPs}$ were also statistically analyzed by one-way ANOVA techniques. Data are presented as mean $\pm \mathrm{SEM}$.

\section{Results and Discussion}

A real-time ECIS monitoring was used for assessing the cytotoxicity of different concentrations $(0,1,5,10$, and $50 \mathrm{mM})$ of $\mathrm{MgO} / \mathrm{Mg}(\mathrm{OH})_{2} \mathrm{NPs}$ in $\mathrm{hFOB} 1.19$ cells. With this sensitive and robust system, impedance was generated with respect to the time to quantify the morphological changes in hFOB 1.19 cells after the treatment. This result provides an allowable concentration of $\mathrm{MgO} / \mathrm{Mg}(\mathrm{OH})_{2} \mathrm{NPs}$ in hFOB 1.19 cells. Based on these real-time study results, we propose the development of sustainable, biodegradable $\mathrm{Mg}$-based alloys for future in vivo testing in orthopedics.

\subsection{The Confluence of hFOB Osteoblast Cells}

Osteoblast differentiation is observed by the stages of cell proliferation, matrix maturation, and mineralization [30]. In addition, in vitro matrix maturation and mineralization increase with the complete confluence of the cells [31].

The results illustrated in Figure 1 shows that after seeding hFOB 1.19 cells for $24 \mathrm{~h}$, the size of the cells changed from round to elongated due to cell differentiation and maturation, and there was approximately $20-30 \%$ confluency. After the first passage, cells were proportionately spread and approximately $30-40 \%$ confluent with a few dead cells at $48 \mathrm{~h}$. After the second passage, cells were spread and approximately 50-60\% confluent, with a reduced number of the dead cells at $72 \mathrm{~h}$. However, after the third passage, cells were elongated, spread, and approximately $70-90 \%$ confluent, with a negligible number of dead cells at $96 \mathrm{~h}$. These optimally confluent hFOB 1.19 cells provided a suitable condition for the assessment of cytotoxicity upon exposure to different concentrations of $\mathrm{MgO} / \mathrm{Mg}(\mathrm{OH})_{2}$ through the real-time ECIS monitoring system. 

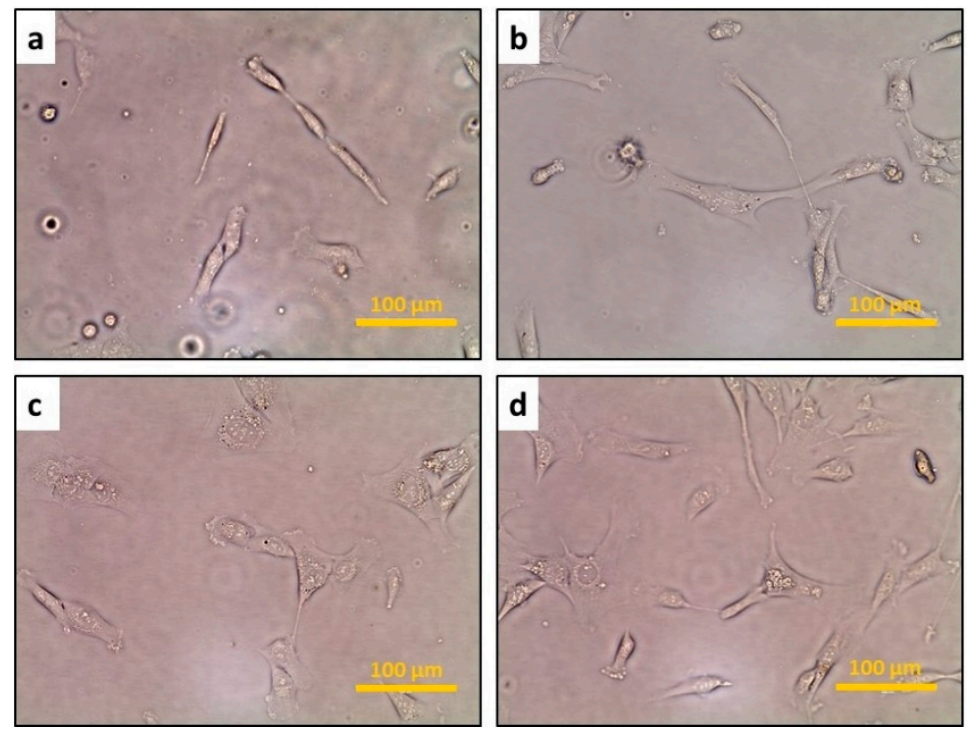

Figure 1. Confluence of human fetal osteoblast (hFOB) 1.19 cells cultured in complete growth media at different time points:(a) $20-30 \%$ of cell confluence at $24 \mathrm{~h}$; (b) $30-40 \%$ of cell confluence at $48 \mathrm{~h}$;

(c) $50-60 \%$ of cell confluence at $72 \mathrm{~h}$; and (d) $70-90 \%$ of cell confluence at $96 \mathrm{~h}$ of seeding.

\subsection{The Response of hFOB Osteoblast Cells on ECIS after Treatment}

The images of hFOB 1.19 cells after treatment with different concentrations $(0,1,5,10$, and $50 \mathrm{mM})$ of $\mathrm{MgO}$ and $\mathrm{Mg}(\mathrm{OH})_{2} \mathrm{NPs}$ at $24 \mathrm{~h}$ on a transparent single circular $250 \mu \mathrm{m}$ diameter active gold electrode of the ECIS system are shown in Figures 2 and 3, respectively. Results in Figure 2 show that after treating hFOB 1.19 cells with $0 \mathrm{mM}$ of MgO NPs at $24 \mathrm{~h}$, cells proliferate, spread, and adhere to the electrode, maintaining a confluent monolayer. At the lower concentration $(1 \mathrm{mM})$ of $\mathrm{MgO}$ NPs, hFOB 1.19 cells show similar proliferation as that of the control group $(0 \mathrm{mM})$, representing normal hemostasis of the cells. However, at the concentrations of 5, 10, and $50 \mathrm{mM}$ of MgO NPs, the subsequent reduction in cell number was observed.
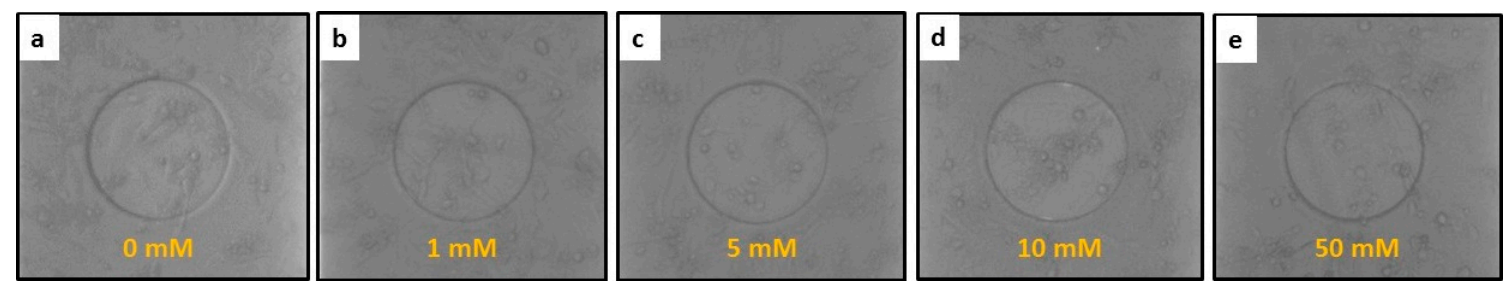

Figure 2. Images of live and dead hFOB 1.19 cells on microfabricated electrodes after treatment with different concentrations of $\mathrm{MgO}$ nanoparticles (NPs) at $24 \mathrm{~h}$ : (a) $0 \mathrm{mM} \mathrm{MgO} \mathrm{NPs} \mathrm{(control} \mathrm{group);}$ (b) $1 \mathrm{mM} \mathrm{MgO} \mathrm{NPs;} \mathrm{(c)} 5$ mM MgO NPs; (d) $10 \mathrm{mM} \mathrm{MgO} \mathrm{NPs;} \mathrm{and} \mathrm{(e)} 50 \mathrm{mM} \mathrm{MgO} \mathrm{NPs}$.
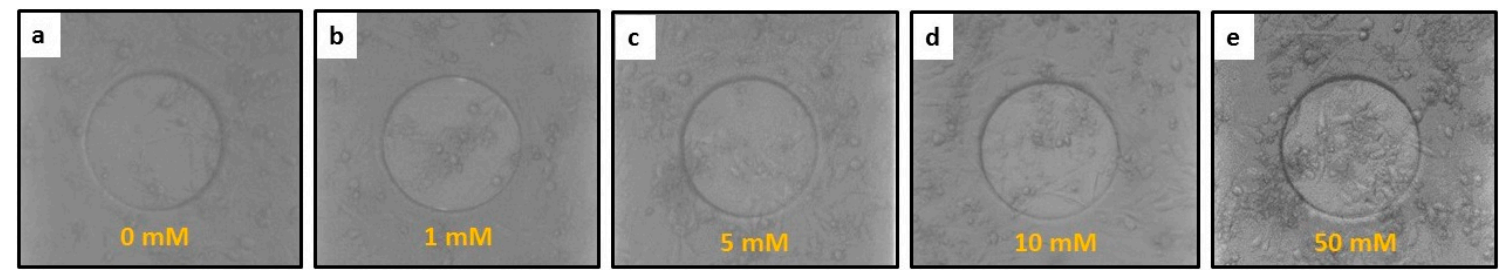

Figure 3. Images of live and dead hFOB 1.19 osteoblast cells on microfabricated electrodes after treatment with different concentrations of $\mathrm{Mg}(\mathrm{OH})_{2} \mathrm{NPs}$ at $24 \mathrm{~h}$ : (a) $0 \mathrm{mM} \mathrm{Mg}(\mathrm{OH})_{2}$ (control group); (b) $1 \mathrm{mM} \mathrm{Mg}(\mathrm{OH})_{2} ;$ (c) $5 \mathrm{mM} \mathrm{Mg}(\mathrm{OH})_{2}$; (d) $10 \mathrm{mM} \mathrm{Mg}(\mathrm{OH})_{2}$; and (e) $50 \mathrm{mM} \mathrm{Mg}(\mathrm{OH})_{2}$. 
Results in Figure 3 show that after treating hFOB 1.19 cells with $0 \mathrm{mM}$ of $\mathrm{Mg}(\mathrm{OH})_{2} \mathrm{NPs}$ at $24 \mathrm{~h}$, cells proliferate, spread, and adhere to the electrode and maintain the uniform monolayer. At the lower concentration $(1 \mathrm{mM})$ of $\mathrm{Mg}(\mathrm{OH})_{2} \mathrm{NPs}$, hFOB 1.19 cells show adhesion; however, the reduction in cell growth was observed as compared to the control group $(0 \mathrm{mM})$. With the concentrations of 5 and $10 \mathrm{mM}$ of $\mathrm{Mg}(\mathrm{OH})_{2} \mathrm{NPs}$, subsequent reduction in cell growth and number of the live cells was observed. With the exposure of the $50 \mathrm{mM}$ concentration of $\mathrm{Mg}(\mathrm{OH})_{2} \mathrm{NPs}$ on the hFOB 1.19 cells, a drastic reduction in the cell growth was observed.

Comparing the reactivity of hFOB 1.19 cells in response to the exposure of $50 \mathrm{mM}$ concentrations of $\mathrm{MgO}$ and $\mathrm{Mg}(\mathrm{OH})_{2} \mathrm{NPs}$ for $24 \mathrm{~h}$, results depict major reduction in cell proliferation and spread for $\mathrm{Mg}(\mathrm{OH})_{2} \mathrm{NPs}$.

\subsection{ECIS Measurement}

ECIS results are shown in Figures 4 and 5 in response to the exposure of different concentrations $(0,1,5,10$, and $50 \mathrm{mM})$ of $\mathrm{MgO} / \mathrm{Mg}(\mathrm{OH})_{2} \mathrm{NPs}$, respectively, on hFOB 1.19 cells. Cells were utilized after three passages to obtain high throughput results through ECIS experiments. Cells were incubated for $24 \mathrm{~h}$ on microelectrodes of the ECIS array for the control group $(0 \mathrm{mM})$ and the experimental groups $(1,5,10$, and $50 \mathrm{mM})$ to evaluate the cytotoxicity of different concentrations of $\mathrm{MgO} / \mathrm{Mg}(\mathrm{OH})_{2} \mathrm{NPs}$ upon exposure. Figures 4 and 5 illustrate an increase in impedance at $24 \mathrm{~h}$ due to the cell proliferation and formation of the monolayer of the cells. Further, a drop in the impedance for an hour has been observed after $24 \mathrm{~h}$ in the samples due to the change of the culture media of the control group and the experimental groups before exposure of the concentrations of $\mathrm{MgO} / \mathrm{Mg}(\mathrm{OH})_{2} \mathrm{NPs}$.

Figure 4 shows the ECIS impedance response to hFOB 1.19 cells upon exposure of different concentrations of MgO NPs for $24 \mathrm{~h}$. At a $0 \mathrm{mM}$ concentration of MgO NPs, a constant monolayer of cells was observed due to rapid cell proliferation, resulting in an increase impedance that saturated at $8700 \Omega$ after $24 \mathrm{~h}$. For the lower concentration $(1 \mathrm{mM})$ of MgO NPs, increased cell proliferation and formation of a monolayer of cells have been observed, which resulted in an increased impedance that saturated at $8600 \Omega$ after $24 \mathrm{~h}$. Nearly similar impedance results for $1 \mathrm{mM}$ concentrations of $\mathrm{MgO}$ NPs and control group $(0 \mathrm{mM})$ indicates the negligible amount of cytotoxicity to the hFOB 1.19 cells. However, at concentrations of 5,10 , and $50 \mathrm{mM}$, a subsequent decrease in the impedance to 8300.4, 8200, and $8080 \Omega$ was reported, respectively, as compared to control group $(0 \mathrm{mM})$ and $1 \mathrm{mM}$ concentration of MgO NPs. The decrease in impedance demonstrates increased cytotoxicity in hFOB 1.19 cells, mainly due to cell death that has been confirmed with the live-cell images of hFOB 1.19 cells on microelectrodes upon exposure, as shown in Figure 2.

Figure 5 shows the ECIS impedance response to hFOB 1.19 cells upon exposure to different concentrations $(0,1,5,10$, and $50 \mathrm{mM})$ of $\mathrm{Mg}(\mathrm{OH})_{2} \mathrm{NPs}$ for $24 \mathrm{~h}$. At $0 \mathrm{mM}$ concentration, a constant monolayer of cells was identified with rapid cell proliferation with an increase of impedance that saturated at $8400 \Omega$ after $24 \mathrm{~h}$. Exposure to a lower concentration, such as $1 \mathrm{mM}$, cell proliferation and formation of a monolayer of cells with an increased impedance that saturated at $8130 \Omega$ after $24 \mathrm{~h}$ was observed. However, at the concentrations of 5, 10, and $50 \mathrm{mM}$, subsequent decreases in the impedance to 7890,7830 , and $7810 \Omega$ were reported, respectively, as compared to control group $(0 \mathrm{mM})$ and $1 \mathrm{mM}$ concentrations of $\mathrm{Mg}(\mathrm{OH})_{2}$ NPs. A subsequent decrease in the impedance results reveals increased cytotoxicity with the higher concentrations of 5,10 , and $50 \mathrm{mM}$ of $\mathrm{Mg}(\mathrm{OH})_{2} \mathrm{NPs}$. Cytotoxicity was also confirmed with the live-cell images of hFOB 1.19 cells on microelectrodes upon exposure, as shown in Figure 3. To access the level of cytotoxicity among the different concentrations of $\mathrm{MgO}$ and $\mathrm{Mg}(\mathrm{OH})_{2} \mathrm{NPs}$ for $24 \mathrm{~h}$, ECIS impedance responses of hFOB 1.19 cells upon exposure have been compared. The combined results of ECIS impedance and the live images depict that $1 \mathrm{mM}$ concentrations of $\mathrm{MgO}$ NPs are less toxic to hFOB 1.19 cells as compared to $1 \mathrm{mM}$ concentrations of $\mathrm{Mg}(\mathrm{OH})_{2} \mathrm{NPs}$. 


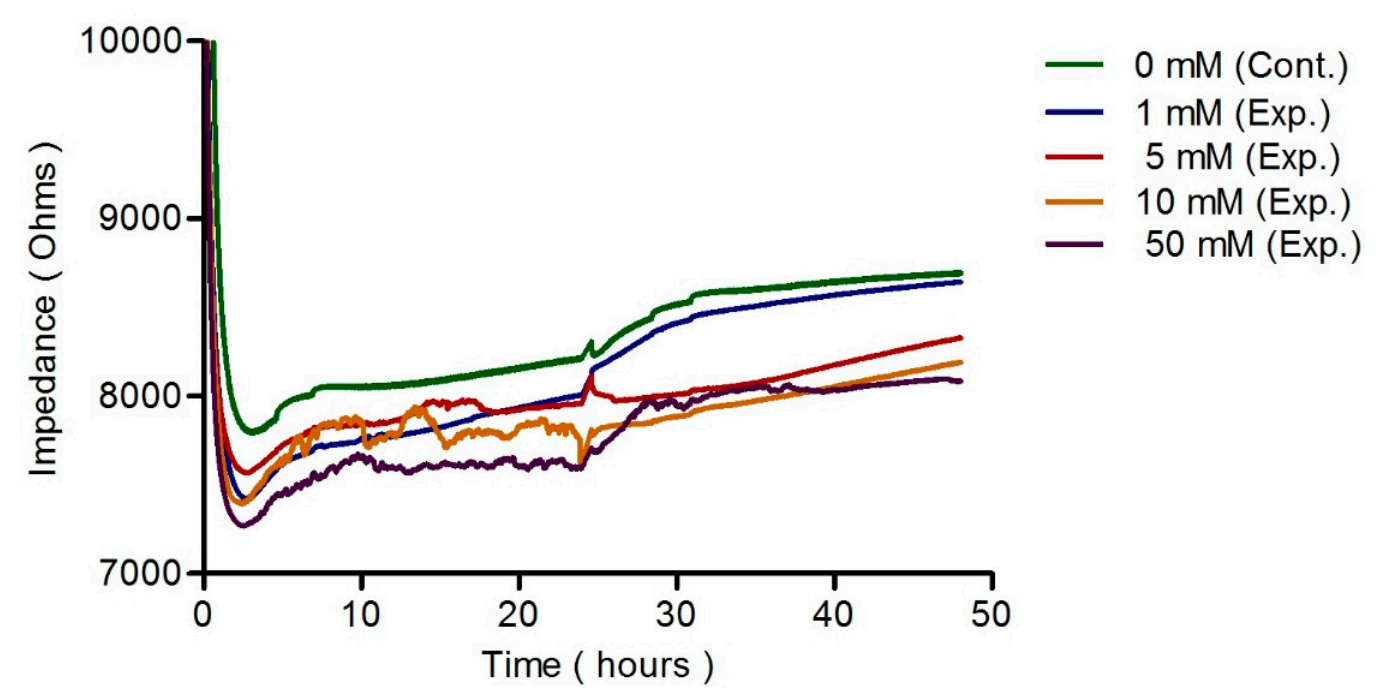

Figure 4. Real-time electric cell-substrate impedance sensing (ECIS) impedance results measuring cytotoxicity in hFOB 1.19 cells in response to different concentrations of MgO NPs.

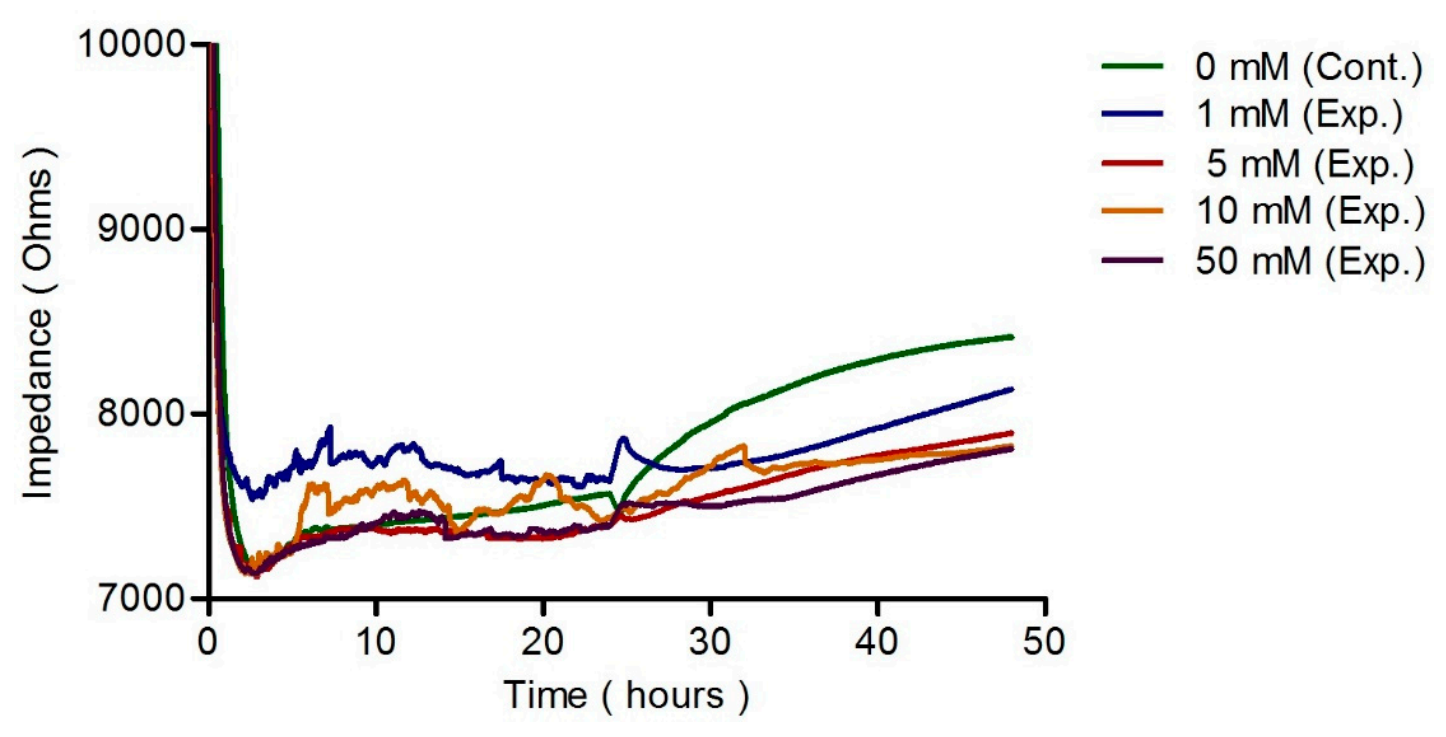

Figure 5. Real-time ECIS impedance results measuring cytotoxicity in hFOB 1.19 cells in response to different concentrations of $\mathrm{Mg}(\mathrm{OH})_{2}$ NPs.

\subsection{Analysis of the $\mathrm{pH}$ Changes}

Figure 6 shows the change in $\mathrm{pH}$ of hFOB 1.19 cells after exposure with different concentrations $(0,1,5,10$, and $50 \mathrm{mM})$ of MgO NPs. Results show that with the increasing concentrations of $\mathrm{MgO} \mathrm{NP}$ exposures in hFOB 1.19 cells, the $\mathrm{pH}$ was more alkaline (mean $\mathrm{pH}$ values: $1 \mathrm{mM}=7.83,5 \mathrm{mM}=8.13$, $10 \mathrm{mM}=8.33,50 \mathrm{mM}=8.83)$ when compared to the control group $(0 \mathrm{mM}=7.53)$. 


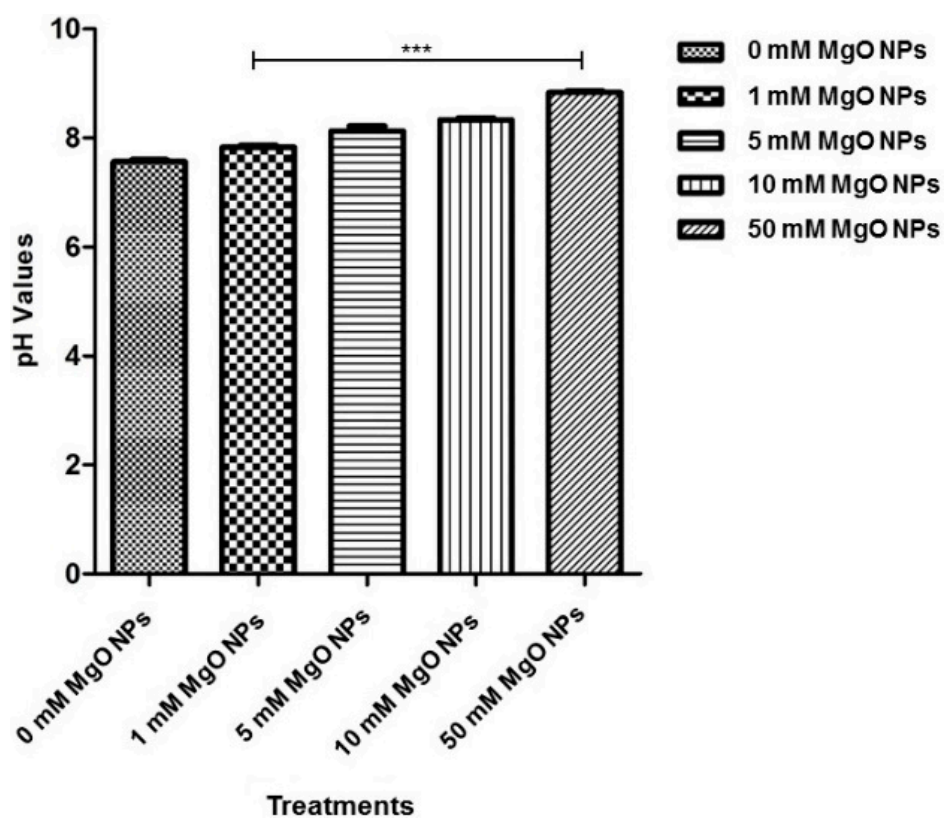

Figure 6. Analysis of the change in $\mathrm{pH}$ in $\mathrm{hFOB} 1.19$ cells in response to the different concentrations of $\mathrm{MgO}$ NPs. Data are obtained as means $\pm \mathrm{SEM}, n=3 ;{ }^{* * *} p$-value $\leq 0.0001$ when compared to the control group.

Figure 7 shows that with the increasing concentrations of $\mathrm{Mg}(\mathrm{OH})_{2}$ NPs exposure in hFOB 1.19 cells, the $\mathrm{pH}$ was more alkaline (mean $\mathrm{pH}$ values: $1 \mathrm{mM}=8.23,5 \mathrm{mM}=8.33,10 \mathrm{mM}=8.57$, $50 \mathrm{mM}=9.07)$ when compared to the control group $(0 \mathrm{mM}=7.57)$.

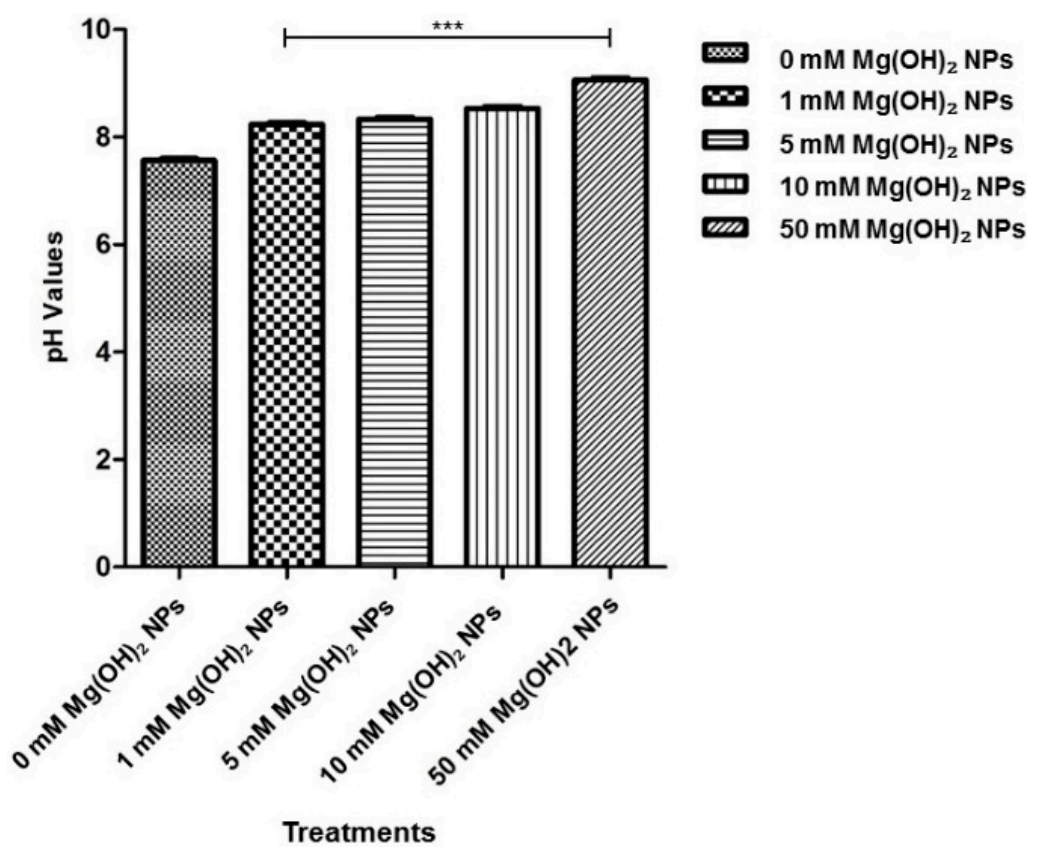

Figure 7. Analysis of the change in $\mathrm{pH}$ in hFOB 1.19 cells in response to the different concentrations of $\mathrm{Mg}(\mathrm{OH})_{2} \mathrm{NPs}$. Data are obtained as means $\pm \mathrm{SEM}, n=3 ;^{* * *} p$-value $\leq 0.0001$ when compared to the control group. 


\subsection{Discussion}

Mg-based biodegradable orthopedic implants dissolve in the physiological environment of the body, producing corrosion products [3,4]. Studies suggest that the degradation behavior of the Mg-based implants varies due to different corrosive environments of in vitro and in vivo studies [5], which makes it challenging to establish $\mathrm{Mg}$ as a next-generation biodegradable material [3,7]. Therefore, in this study, we used a real-time ECIS system to mimic the in vivo environment for assessing the cytotoxicity of different concentrations $(0,1,5,10$, and $50 \mathrm{mM})$ of $\mathrm{MgO} / \mathrm{Mg}(\mathrm{OH})_{2} \mathrm{NPs}$ in hFOB 1.19 cells [7]. Based on our findings by real-time ECIS study, we propose the development of sustainable, biodegradable Mg-based alloys as the implant materials for orthopedic applications.

Osteoblast differentiation progresses by the process of cell proliferation, matrix maturation, and mineralization [30]. In the case of the in vitro environment, the complete confluence of the cells increases matrix maturation and mineralization [31]. Magnesium homeostasis and regulation of cell functions such as cell proliferation, energy metabolism, and the apoptosis process in healthy and diseased cells are also reported [32]. Therefore, in our study, we investigated the confluence of the hFOB 1.19 cells for 24, 48, 72, and 96 h [7] before ECIS experiments. Results show that after $96 \mathrm{~h}$, cells were approximately $70-80 \%$ confluent with a negligible number of dead cells when compared to 72 ( $50-60 \%$ confluence), 48 (30-40\% confluence), and $24 \mathrm{~h}$ ( $20-30 \%$ confluence). The maximum convergence of hFOB 1.19 cells significantly contributes to avoiding any false-positive results with dead cells that might otherwise interfere with the ECIS impedance upon exposure to $\mathrm{MgO} / \mathrm{Mg}(\mathrm{OH})_{2}$ NPs [7].

The ECIS impedance result reveals that $1 \mathrm{mM}$ concentrations of MgO NPs provide a similar range of impedance as the control group $(0 \mathrm{mM})$, which indicates magnesium homeostasis, as shown in Figure 4 . However, at the subsequent higher concentrations, such as 5,10 , and $50 \mathrm{mM}$ concentrations of $\mathrm{MgO}$ NPs [7], the impedance drops significantly, indicating cytotoxicity by inhibiting cell proliferation. Comparative impedance results of $\mathrm{MgO}$ and $\mathrm{Mg}(\mathrm{OH})_{2} \mathrm{NPs}$ [7] in Figures 4 and 5, respectively, show that impedance is lower at $50 \mathrm{mM}$ concentrations of $\mathrm{Mg}(\mathrm{OH})_{2} \mathrm{NPs}$ [7] when compared to MgO NPs [7], which indicates high cytotoxicity of $\mathrm{Mg}(\mathrm{OH})_{2}$ at $50 \mathrm{mM}$. These results have been confirmed by the images of live and dead cells on microfabricated electrodes in Figures 2 and 3, respectively.

Studies suggest that extracellular $\mathrm{pH}$ and oxygen tension alters the bone hemostasis [29]. Besides, the skeleton serves as the reservoir of alkaline mineral (hydroxyapatite), which releases in case of metabolic acid-base imbalance [33]. Also, reports on bone cells suggest that at acidic $\mathrm{pH}$, osteoblast activity inhibits, which results in inhibition of mineral deposition [29,33]. However, the bone resorption activity of osteoclast cells gets activated at acidic $\mathrm{pH}$ [33]. The changes in $\mathrm{pH}$ levels of the possible corrosion products are not entirely understood. Therefore, with this study, insight into the change in $\mathrm{pH}$ of different concentrations of $\mathrm{MgO} / \mathrm{Mg}(\mathrm{OH})_{2} \mathrm{NPs}$ upon exposure to hFOB 1.19 cells [7] has also been gained.

Little evidence of the in vitro test to study the cytotoxicity of the corrosion products is reported [7]. However, in this study, we provide real-time in vitro ECIS results for an allowable concentration of $\mathrm{MgO} / \mathrm{Mg}(\mathrm{OH})_{2} \mathrm{NPs}$ in hFOB 1.19 cells. With the results obtained from our study, we propose the development of sustainable, biodegradable $\mathrm{Mg}$-based alloys for future in vivo testing for orthopedic implant applications.

\section{Conclusions}

Mg-based orthopedic implants have an added advantage due to their biodegradation behavior, which can eliminate the requirement of a second surgery to remove implant after they support, repair, and heal bones. However, cytotoxicity of the possible corrosion products in the form of $\mathrm{MgO} / \mathrm{Mg}(\mathrm{OH})_{2}$ NPs that might be released during the process of implant degradation is not entirely understood. Currently, little evidence of in vitro assessment of the cytotoxicity of the possible corrosion products in osteoblast cells has been reported [7]. Conversely, there is a need to access the cytotoxicity of the potential corrosion products in a real-time manner for the future development of sustainable, 
biodegradable Mg-based alloys for in vivo animal testing and clinical trials in orthopedics. Therefore, in our study, we assessed the cytotoxicity of different concentrations $(0,1,5,10$, and $50 \mathrm{mM})$ of $\mathrm{MgO} / \mathrm{Mg}(\mathrm{OH})_{2} \mathrm{NPs}$ in hFOB 1.19 cells [7] using a real-time ECIS monitoring system. Our results show that $1 \mathrm{mM}$ concentrations of $\mathrm{MgO} / \mathrm{Mg}(\mathrm{OH})_{2}$ NPs are an allowable concentration in hFOB 1.19 cells. We propose the development of sustainable, biodegradable Mg-based alloys for future in vivo animal testing and clinical trials for commercial application in the orthopedic implants industry.

Author Contributions: Conceptualization, Y.Y. and J.W.; methodology, Y.K.; software, M.P., validation, M.P. and Y.Y.; formal analysis M.P. and Y.Y., Investigation, M.P.; Resources, J.S.; data curation, M.P.; writing-original draft preparation, M.P.; writing-review and editing, Y.Y., M.P., and J.W.; visualization, M.P.; supervision, Y.Y. and J.S.; project administration, J.W. and J.S.; funding acquisition, Y.Y. and J.S. [7]. All authors have read and agreed to the published version of the manuscript.

Funding: This research received funding from the National Science Foundation Engineering Research Center for Revolutionizing Metallic Biomaterials, NIH grant (GM113728), ARO grant (74386), and NSF grant (1649243) [7].

Conflicts of Interest: The authors declare no conflict of interest.

\section{References}

1. Witte, F.; Kaese, V.; Haferkamp, H.; Switzer, E.; Meyer-Lindenberg, A.; Wirth, C.J.; Windhagen, H. In vivo corrosion of four magnesium alloys and the associated bone response. Biomaterials 2005, 26, 3557-3563. [CrossRef] [PubMed]

2. Staiger, M.P.; Pietak, A.M.; Huadmai, J.; Dias, G. Magnesium and its alloys as orthopedic biomaterials: A review. Biomaterials 2006, 27, 1728-1734. [CrossRef] [PubMed]

3. McBride, E.D. Absorbable metal in bone surgery. J. Am. Med. Assoc. 1938, 111, 2464-2467. [CrossRef]

4. Verbrugge, J. Le Mate' riel Métallique Re’sorbable En Chirurgie Osseuse. La Press Med. 1934, 23, 460-465.

5. Williams, D.F. Effects of the environment on materials. Biomed. Eng. 1971, 6, 106-113. [PubMed]

6. Witte, F.; Fischer, J.; Nellesen, J.; Crostack, H.A.; Kaese, V.; Pisch, A.; Beckmann, F.; Windhagen, H. In vitro and in vivo corrosion measurements of magnesium alloys. Biomaterials 2006, 27, 1013-1018. [CrossRef] [PubMed]

7. Pallavi, M.; Waterman, J.; Koo, Y.; Sankar, J.; Yun, Y. In Vitro Cytotoxicity of Possible Corrosion Products from Mg-Based Biodegradable Metals: Magnesium Oxide and Magnesium Hydroxide Nanoparticles. Appl. Sci. 2019, 9, 4304. [CrossRef]

8. Günther, T. Comment on the number of magnesium activated enzymes. Magnes. Res. 2008, 1, $185-187$.

9. Rubin, H. Magnesium: The missing element in molecular views of cell proliferation control. Bioessays. 2005, 27, 311-320. [CrossRef]

10. Yun, Y.; Dong, Z.; Lee, N.; Liu, Y.; Xue, D.; Guo, X.; Kuhlmann, J.; Doepke, A.; Halsall, H.B.; Heineman, W.; et al. Revolutionizing biodegradable metals. Mater. Today 2009, 12, 22-32. [CrossRef]

11. McCarthy, T.J.; Kumar, R. Divalent Cation Metabolism: Magnesium. In Atlas of Diseases of the Kidney; Schrier, R.W., Ed.; Blackwell Science: Malden, MA, USA, 1999; pp. 4.1-4.8.

12. Al-Ghamdi, S.M.G.; Cameron, E.C.; Sutton, R.A.L. Magnesium deficiency: Pathophysiologic and clinical overview. Am. J. Kidney Dis. 1994, 24, 737-752. [CrossRef]

13. De Rouffignac, C.; Quamme, G. Renal magnesium handling and its hormonal control. Physiol. Rev. 1994, 74, 305-322. [CrossRef] [PubMed]

14. McLean, R.M. Magnesium and its therapeutic uses: A review. Am. J. Med. 1994, 96, 63-76. [CrossRef]

15. Quamme, G.A. Magnesium homeostasis and renal magnesium handling. Miner. Electrolyte Metab. 1993, 19, 218-225.

16. Nadler, J.L.; Rude, R.K. Disorders of magnesium metabolism. Endocrin. Metab. Clin. 1995, $24,623-641$. [CrossRef]

17. Whang, R.; Hampton, E.M.; Whang, D.D. Magnesium homeostasis and clinical disorders of magnesium deficiency. Ann. Pharmacother. 1994, 28, 220-226. [CrossRef]

18. Abed, E.; Moreau, R. Importance of melastatin-like transient receptor potential 7 and magnesium in the stimulation of osteoblast proliferation and migration by platelet-derived growth factor. Am. J. Physiol. Cell Phys. 2009, 297, C360-C368. [CrossRef]

19. Anselme, K. Osteoblast adhesion on biomaterials. Biomaterials 2000, 21, 667-681. [CrossRef] 
20. Diener, A.; Nebe, B.; Lüthen, F.; Becker, P.; Beck, U.; Neumann, H.G.; Rychly, J. Control of focal adhesion dynamics by material surface characteristics. Biomaterials 2005, 26, 383-392. [CrossRef]

21. Hornby, J.E. Measurement of cell adhesion. II. Quantitative study of the effect of divalent ions on cell adhesion. J. Embryol. Exp. Morph. 1973, 30, 511-518.

22. Li, C.Y.; Gao, S.Y.; Terashita, T.; Shimokawa, T.; Kawahara, H.; Matsuda, S.; Kobayashi, N. In vitro assays for adhesion and migration of osteoblastic cells (Saos-2) on titanium surfaces. Cell Tissue Res. 2006, 324, 369-375. [CrossRef] [PubMed]

23. Maier, J.A.; Bernardini, D.; Rayssiguier, Y.; Mazur, A. High concentrations of magnesium modulate vascular endothelial cell behaviour in vitro. Biochim. Biophys. Acta. 2004, 1689, 6-12. [CrossRef] [PubMed]

24. Moomaw, A.S.; Maguire, M.E. The unique nature of mg2+ channels. Physiology 2008, 23, 275-285. [CrossRef] [PubMed]

25. Rouahi, M.; Champion, E.; Hardouin, P.; Anselme, K. Quantitative kinetic analysis of gene expression during human osteoblastic adhesion on orthopaedic materials. Biomaterials 2006, 27, 2829-2844. [CrossRef]

26. Spillmann, C.; Osorio, D.; Waugh, R. Integrin activation by divalent ions affects neutrophil homotypic adhesion. Ann. Biomed. Eng. 2002, 30, 1002-1011. [CrossRef]

27. Turner, D.; Flier, L.; Carbonetto, S. Magnesium-dependent attachment and neurite outgrowth by PC12 cells on collagen and laminin substrata. Dev. Biol. 1987, 121, 510-525. [CrossRef]

28. Zreiqat, H.; Howlett, C.R.; Zannettino, A.; Evans, P.; Schulze-Tanzil, G.; Knabe, C.; Shakibaei, M. Mechanisms of magnesium-stimulated adhesion of osteoblastic cells to commonly used orthopaedic implants. J. Biomed. Mater. Res. 2002, 62, 175-184. [CrossRef]

29. Arnett, T.R. Extracellular pH Regulates Bone Cell Function. J. Nutr. 2008, 138, 415S-418S. [CrossRef]

30. Stein, G.S.; Lian, J.B. Molecular Mechanisms Mediating Developmental and Hormone-Regulated Expression of Genes in Osteoblasts: An Integrated Relationship of Cell Growth and Differentiation. In Cellular Molecular Biology of Bone; Noda, M., Ed.; Academic Press: Tokyo, Japan, 1993; pp. 47-95.

31. Kasperk, C.; Wergedal, J.; Strong, D.; Farley, J.; Wangerin, K.; Gropp, H.; Ziegler, R.; Baylink, D.J. Human bone cell phenotypes differ depending on their skeletal site of origin. J. Clin. Endocr. Metab. 1995, 80, 2511-2517.

32. Wolf, F.; Trapani, V. Cell (patho) physiology of magnesium. Clin. Sci. 2008, 114, 27-35. [CrossRef]

33. Arnett, T.R. Acidosis, hypoxia and bone. Arch. Biochem. Biophys. 2010, 503, 103-109. [CrossRef] [PubMed] 